\title{
THE AVAILABILITY OF PHYSICAL EDUCATION FACILITIES AT PUBLIC EDUCATION INSTITUTIONS IN HUNGARY
}

\author{
Gábor KOZMA* \\ University of Debrecen, Faculty of Science and Technology, Institute of Earth Sciences, Department of Social Geography \\ and Regional Development Planning, Egyetem tér 1, 4032 Debrecen, Hungary, e-mail: kozma.gabor@ science.unideb.hu
}

Citation: Kozma, G. (2020). The Availability of Physical Education Facilities at Public Education Institutions in Hungary. Analele Universităţii din Oradea, Seria Geografie, 30(1), 65-75. https://doi.org/10.30892/auog.301108-849

\begin{abstract}
Taking into account the importance of exercise the main aim of this paper is to examine the availability of physical education facilities at Hungarian primary and secondary schools, and their territorial characteristics. As a result it can be stated that the situation of these institutions in this regard is fundamentally favourable. On the other hand the spatial characteristics of these facilities is influenced by different factors from which in the case of districts the level the development and the number of population and on settlement level the number of population plays the most decisive role.
\end{abstract}

Key words: physical education, public education facilities, spatial characteristics, Hungary

$* \quad * \quad * \quad * \quad * \quad *$

\section{INTRODUCTION}

Nowadays the increasing role of sport geography can be witnessed within the field of geography (Bánhidi, 2011; Ilies et al., 2014; Wise and Koche, 2020). One of its topics is the examination of the spatial distribution of sport facilities (e.g. Kozma, 2014; Hoekman et al., 2016), since these infrastructural elements represent an important condition of increasing the physical activity of society. Among sports facilities, a special role is played by relevant spaces in public education institutions, since the purpose of these is to provide the given age group with an opportunity to engage in regular physical exercise, which is of key importance for a number of reasons (see later).

In the spirit of the above, this paper intends to examine the availability of physical education (PE) facilities at Hungarian public education institutions (primary and secondary schools), as well as the territorial characteristics of the above, to identify which administrative districts/settlements are in the worst position, unable to satisfy the conditions prescribed by the relevant provisions of law, as well as what factors influence the location of the territorial units concerned.

\footnotetext{
${ }^{*}$ Corresponding Author
} 
The paper fundamentally consists of three larger parts. The first part discusses the significance of physical education in public education institutions (with special attention to the requirements in effect in Hungary), which is followed by an analysis of the current Hungarian situation. The last part summarizes the most important findings.

\section{THE SIGNIFICANCE OF PHYSICAL EDUCATION}

Physical education in schools plays an important role in the development of the age group concerned for a number of reasons (Mikulan, 2013). Firstly, achieving the amount of physical activity, as established by researchers (e.g. Strong, et al., 2005) as the daily minimum (60 minutes at the age of 5 to 18), especially in today's digital world, is often only possible with the help of the physical education classes (Tassatino et al., 2010; Dobi and Bácsné Bába, 2018), which has a favourable influence on both the health and psychological condition of students (Dubbert, 2002; Tsang, 2011; Baidog and Herman, 2018; Tătar et al., 2018; Papp et al., 2019; Erdely et al., 2020). Secondly, both the study summarizing the findings of research projects on this topic (Marques et al., 2017), and also concrete case studies have come to the conclusion that physical activity generally has a favourable effect on students' academic performance. They have pointed out, among other things, that students' cognitive capabilities (e.g. verbal argumentation), as well as their academic results (e.g. their grades in mathematics, literature and foreign languages) improved as a result of more intensive physical activity (Van Dusen et al., 2011; Ardoy et al., 2014).

Thirdly, positive experiences gained in physical education classes have a significant force on shaping students' personalities (Gordon-Larsen et al., 2000; Polet, 2019), and they reinforce their commitment to active lifestyle (which is particularly important because physical education classes in school often do not provide sufficient time for necessary daily physical exercise). Fourthly, lessons that provide for the exercise of various body parts and muscles, as well as getting acquainted with different physical/sporting activities, make the harmonic development of the human body possible (Hagger et al., 2003).

What gives special significance to the research project is that, as a result of the factors discussed earlier, the Hungarian government, in power since 2010, devotes great attention to physical education. This is reflected by the fact that, pursuant to Act CXC of 2011, everyday physical education was introduced from 1 September 2012; at the same time, organizing this posed a major challenge for the schools. The concrete requirements are included in Ministerial Decree 20/2012 (VIII. 31.) EMMI (Ministry of Human Capacities) on the Operation of Public Education Institutions and on the Use of Names of Public Education Institutions, according to Annex 2 of which, schools must have the facilities suitable for this purpose (table 1).

Table 1. The requirements of Ministerial Decree 20/2012 (VIII. 31.) EMMI on the facilities of institutes of public educations related to physical education

(Data source: Ministerial Decree 20/2012 (VIII. 31.) EMMI)

\begin{tabular}{|l|l|}
\hline School type & Facility type \\
\hline primary schools, general grammar schools & $1 \mathrm{gym} / \mathrm{school}$ (at the registered seat and branches) \\
\hline $\begin{array}{l}\text { vocational grammar schools, vocational secondary } \\
\text { schools, trade schools, if they teach general } \\
\text { academic subjects }\end{array}$ & $1 \mathrm{gym} / \mathrm{school}$ (at the registered seat and branches) \\
\hline $\begin{array}{l}\text { trade schools only, if they have a capacity over } 120 \\
\text { students }\end{array}$ & $1 \mathrm{gym} /$ school (at the registered seat and branches) \\
\hline $\begin{array}{l}\text { vocational secondary schools, vocational grammar } \\
\text { schools, if they are not required to have a gym, or } \\
\text { the gym is at the registered seat and it is not } \\
\text { possible to use it }\end{array}$ & $\begin{array}{l}1 \mathrm{gym} \text { room or half gym/school (at the registered } \\
\text { seat and branches) }\end{array}$ \\
\hline all school types & $\begin{array}{l}1 \text { sports yards (tracks)/school (at the registered seat } \\
\text { and branches, can be substituted by free space } \\
\text { suitable for the purpose, outdoor facilities) }\end{array}$ \\
\hline
\end{tabular}




\section{DATABASE AND METHODS USED}

In the course of the research for this paper, the most important source of information was the KIR (Public Education Information System) database of the Educational Authority, which includes information on the physical education facilities (gym room, gym, swimming pool, sports yards) in a breakdown according to campuses (or "places of task performance," to use the relevant legal term) in case of schools consisting of several such units. The difference between a gym and a gym room is one of size: according to the relevant Hungarian rules, a gym must be at least $18 \times 30$ metres in size, while smaller facilities are classified as gym rooms.

In the course of the territorial analysis, in order to ensure comparability, we assigned points on the basis of the various types of facilities available (table 2), and then calculated a cumulative value from these for the counties, districts and settlements.

Table 2. The calculation of points for the territorial-level analysis

(Data source: own work)

\begin{tabular}{|l|c|}
\hline types of facilities available & points \\
\hline there are not any facilities & 1 \\
\hline sport yards only & 2 \\
\hline gym room only & 2 \\
\hline gym only & 3 \\
\hline gym room and gym & 4 \\
\hline gym room and sport yards & 4 \\
\hline gym and sport yards & 5 \\
\hline both of them & 6 \\
\hline
\end{tabular}

\section{RESULTS}

We can draw several important conclusions in connection with the availability of physical education facilities in primary and secondary schools (table 3). In terms of the general characteristics, firstly, we can conclude that the availability of swimming pools is very low, as less than $3 \%$ of all institutions provide this possibility (consequently, this type of facility will not be dealt with subsequently). Secondly, it is positive finding that the figure concerning the capacity of the institutions and the actual number of students enrolled is higher in almost every case than the relevant value calculated in case of the number of the institutions, which suggests that the lower level of availability with respect to the PE facilities is fundamentally true for schools operating with fewer students. Thirdly, among the data pertaining to the number of institutions and the number of students, the smallest difference can be found in case of gym rooms, which indicates that these are primarily typical of institutions operating with the smallest number of students.

A comparison of the two types of schools reveals that primary schools are better equipped with PE facilities; at the same time, it is also true that in terms of the capacities and especially the actual number of students enrolled in these institutions, the difference is already much smaller.

Table 3. The availability of physical education facilities at public education institutes (\%) (Data source: KIR database of the Educational Authority)

\begin{tabular}{|l|c|c|c|c|c|c|}
\hline & \multicolumn{3}{|c|}{ primary schools } & \multicolumn{3}{c|}{ secondary schools } \\
\cline { 2 - 7 } & 1 & 2 & 3 & 1 & 2 & 3 \\
\hline has a gym room & 40.0 & 42.3 & 42.9 & 33.1 & 35.9 & 40.6 \\
\hline has a full-scale gym & 70.7 & 82.5 & 84.3 & 63.0 & 73.0 & 80.4 \\
\hline has sport yards & 63.3 & 70.7 & 72.1 & 53.5 & 60.4 & 66.0 \\
\hline has a swimming pool & 2.3 & 3.3 & 3.6 & 2.4 & 2.1 & 2.5 \\
\hline
\end{tabular}

1 - in terms of the number of institutions, 2 - in terms of the capacity of the institutions, 3 - in terms of the actual number of enrolled students 
Analysing the availability of facilities in a complex manner (table 4), a much more detailed picture can be painted. Fundamentally, it can be regarded as favourable that, on the one hand, more than $50 \%$ of the schools have both outdoor (sports yard) and indoor (gym room or gym) facilities for their students, and on the other hand, more than $2 / 3$ of all students attend these schools. The biggest difference between the two types of schools can be found in case of institutions that do not have suitable infrastructural conditions at all, which is basically due to the fact that several grammar schools have such campuses, operating on a settlement other than the registered seat of the institution, with only a low number of students enrolled, where they do not have the possibility to provide the necessary conditions for physical education.

Table 4. The complex availability of physical education facilities at public education institutes (\%) (Data source: KIR database of the Educational Authority)

\begin{tabular}{|l|c|c|c|c|c|c|}
\hline \multirow{2}{*}{ available facilities } & \multicolumn{3}{|c|}{ primary schools } & \multicolumn{3}{c|}{ secondary schools } \\
\cline { 2 - 7 } & 1 & 2 & 3 & 1 & 2 & 3 \\
\hline there are not any facilities & 6.8 & 4.0 & 3.7 & 26.7 & 19.0 & 12.9 \\
\hline sport yards only & 3.9 & 2.6 & 2.3 & 2.7 & 2.0 & 1.5 \\
\hline gym room only & 9.6 & 5.0 & 4.3 & 3.8 & 2.7 & 2.2 \\
\hline gym only & 15.1 & 13.2 & 12.5 & 11.3 & 12.2 & 12.1 \\
\hline gym room and gym & 5.0 & 7.0 & 7.3 & 4.7 & 5.7 & 6.7 \\
\hline gym room and sport yards & 8.8 & 5.8 & 5.3 & 3.8 & 3.2 & 3.0 \\
\hline gym and sport yards & 34.2 & 37.9 & 38.6 & 26.1 & 30.9 & 32.8 \\
\hline both of them & 16.6 & 24.6 & 26.0 & 20.9 & 21.2 & 28.7 \\
\hline total & 100.0 & 100.0 & 100.0 & 100.0 & 100.0 & 100.0 \\
\hline
\end{tabular}

1 - in terms of the number of institutions, 2 - in terms of the capacity of the institutions, 3 - in terms of the actual number of enrolled students

The analysis of the relationship between the availability of facilities and the number of pupils enrolled fundamentally confirms the above (table 5): schools with fewer than 100 pupils are in the worst position (in case of secondary schools, more than 50\% are not able to offer any facilities), while nearly $3 / 4$ of the largest schools have both outdoor and indoor facilities that satisfy the relevant requirements.

Table 5. The availability of physical education facilities at schools as a function of students enrolled (\%) (Data source: KIR database of the Educational Authority)

\begin{tabular}{|l|c|c|c|c|c|c|c|c|}
\hline & \multicolumn{4}{|c|}{ primary schools } & \multicolumn{4}{c|}{ secondary schools } \\
\hline & 1 & 2 & 3 & 4 & 1 & 2 & 3 & 4 \\
\hline there are not any facilities & 13.6 & 6.6 & 2.7 & 1.1 & 58.3 & 33.1 & 12.9 & 7.1 \\
\hline sport yards only & 5.5 & 5.2 & 1.7 & 0.0 & 3.9 & 4.0 & 2.9 & 0.5 \\
\hline gym room only & 24.2 & 6.7 & 2.9 & 1.4 & 4.8 & 7.6 & 2.7 & 1.0 \\
\hline gym only & 16.1 & 19.0 & 11.0 & 6.7 & 9.2 & 9.9 & 13.1 & 12.5 \\
\hline gym room and gym & 2.8 & 3.3 & 8.3 & 9.2 & 1.4 & 6.0 & 3.2 & 7.8 \\
\hline gym room and sport yards & 14.5 & 10.3 & 3.5 & 1.4 & 3.4 & 6.3 & 4.3 & 2.0 \\
\hline gym and sport yards & 18.4 & 39.2 & 38.6 & 43.7 & 12.6 & 19.5 & 35.4 & 34.3 \\
\hline both of them & 4.8 & 9.8 & 31.3 & 31.6 & 6.4 & 13.6 & 25.5 & 34.8 \\
\hline total & 100.0 & 100.0 & 100.0 & 100.0 & 100.0 & 100.0 & 100.0 & 100.0 \\
\hline
\end{tabular}

1 - less than 100 pupils, 2 - 101-250 pupils, 3 - 251-500 pupils, 4 - more than 500 pupils

On the county level, no clear tendencies can be identified on the basis of an examination of the availability of facilities (figures 1 and 2). If we examine the two types of institutions combined, the territorial units with the best results (Zala, Somogy, Csongrád, Jász-Nagykun-Szolnok counties, as well as Budapest) are scattered across the country, while many of those in the worst position are located in the middle of the country, along a wide North-South axis. In case of 
primary schools, the territorial units in the most favourable position are scattered across the country, while in case of secondary schools, it is mainly the counties along the western border of the country that are in this category.

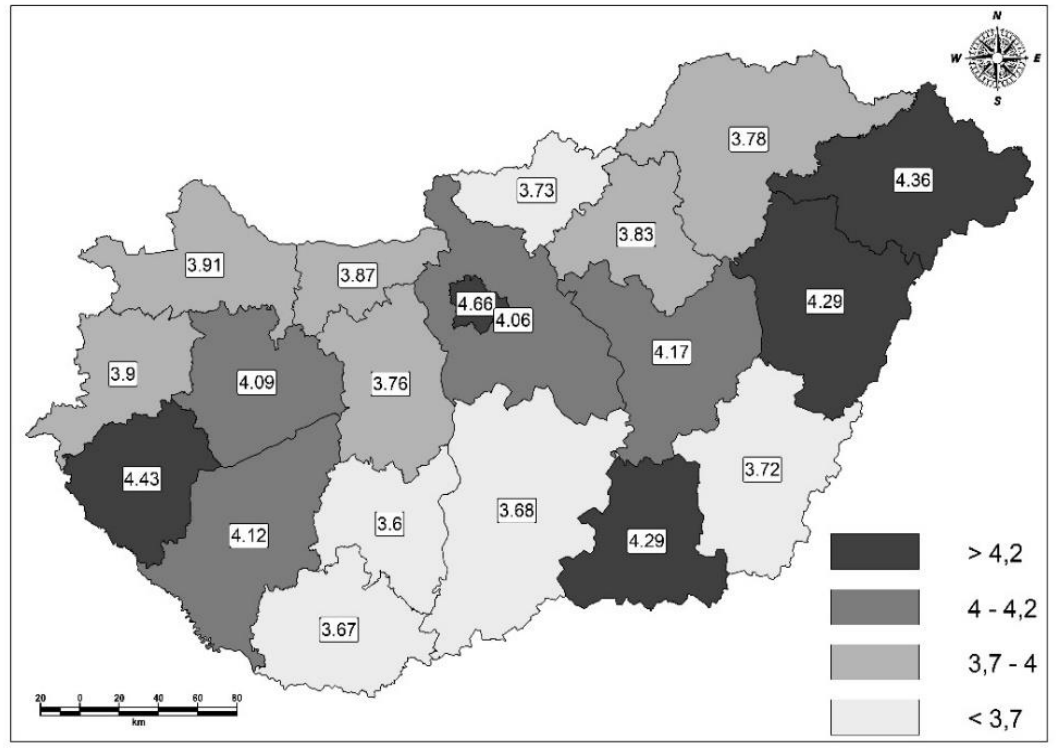

Figure 1. The availability of PE facilities in primary schools on the county level in Hungary (on the basis of the method described in Table 2)

Source: KIR database of the Educational Authority

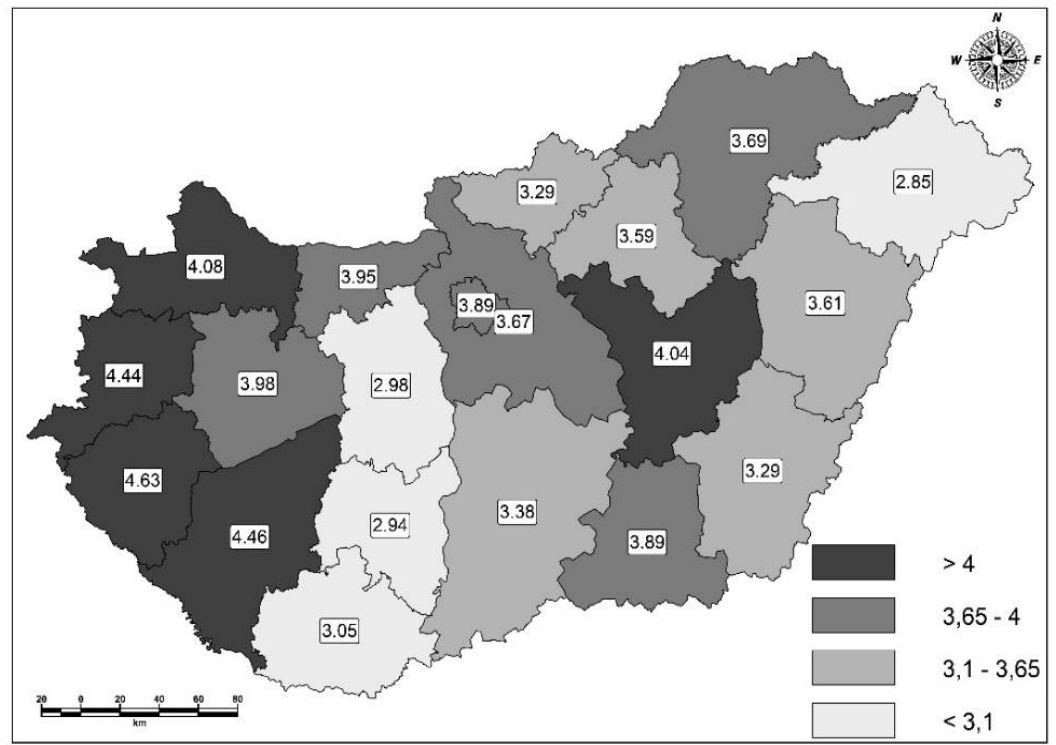

Figure 2. The availability of PE facilities in secondary schools on the county level in Hungary (on the basis of the method described in Table 2)

Source: KIR database of the Educational Authority 
When carrying out the analyses on the district level (figure 3 and 4), a significant difficulty was posed by the fact that in nearly half of the districts (i.e. a total of 78 districts), there was not a high enough number of schools (at least 4) that would have allowed a reliable analysis to be carried out; therefore, the analysis was restricted to 96 districts.

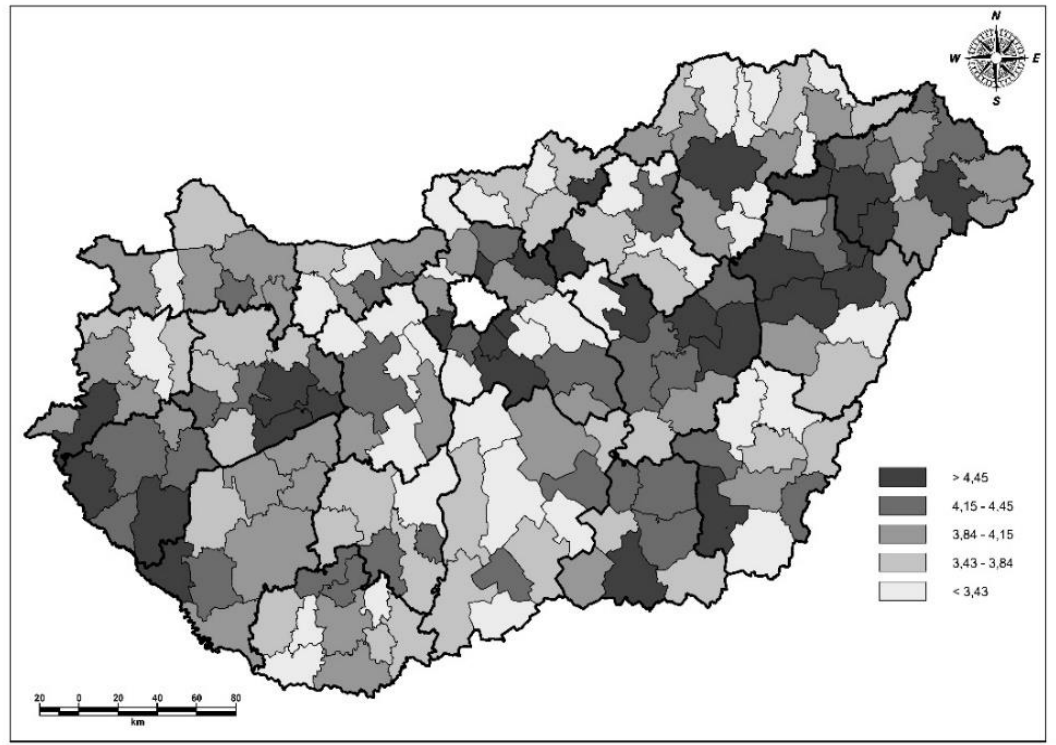

Figure 3. The availability of PE facilities in primary schools on the district level in Hungary (on the basis of the method described in Table 2)

Source: KIR database of the Educational Authority

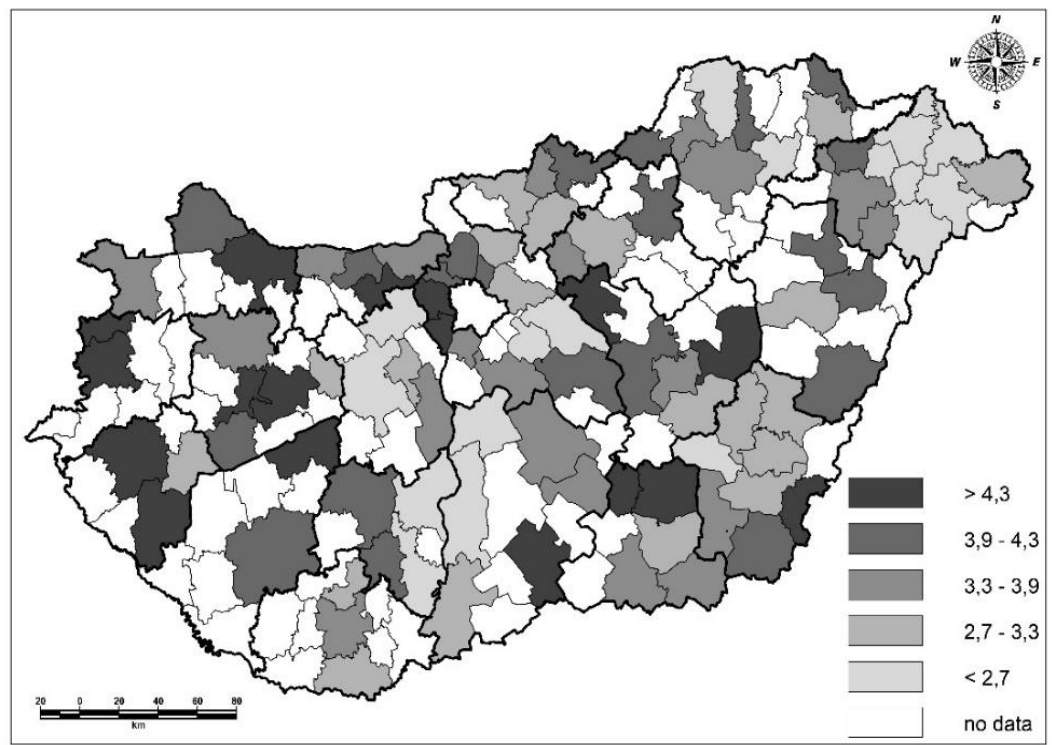

Figure 4. The availability of PE facilities in secondary schools on the district level in Hungary (on the basis of the method described in Table 2)

Source: KIR database of the Educational Authority 
The results show a highly varied picture: both in case of primary and secondary schools it can be observed that even in the counties that are in the best position there are some districts that have unfavourable indicators, and conversely, even in the counties with the worst results there are some districts with good scores. This fact necessitates further, more in-depth research.

Based on the result of our earlier examinations (Kozma, 2020), we devoted more attention to two of the factors influencing the availability of PE facilities at schools in the individual districts: the level of socio-economic development in the given territorial unit and the average population size of the settlements in that unit.

In case of primary schools, the organisation of the data into deciles did not reveal any clear tendencies (table 6): even though the availability of PE facilities increases in a parallel way with the level of development and the average population size of the settlements, we can still observe 1 or 2 groups lagging behind in both cases.

At the same time, the use of various mathematical indicators shows a much clearer picture (table 7): the values of both Spearman's and Pearson's correlation coefficients are higher in case of settlements with an average population size. However, it should also be noted here that the values fundamentally refer to a relationship that is weaker than medium.

Table 6. The availability of PE facilities in primary schools as a subject of the districts' level of development and the average population size of the district's settlements (on the basis of the method presented in Table 2 , the average score assigned to the schools in the given decile)

(Data source: KIR database of the Educational Authority, 290/2014. (XI. 26.) on the classification of beneficiary districts, National Territorial Development and Spatial Planning Information System)

\begin{tabular}{|l|c|c|}
\hline & $\begin{array}{c}\text { the level of development of the } \\
\text { district }\end{array}$ & $\begin{array}{c}\text { the average population size of the } \\
\text { settlements in the district }\end{array}$ \\
\hline first decile & 3.62 & 3.59 \\
\hline second decile & 3.74 & 3.93 \\
\hline third decile & 3.64 & 3.90 \\
\hline fourth decile & 3.79 & 3.89 \\
\hline fifth decile & 3.91 & 3.71 \\
\hline sixth decile & 3.78 & 3.90 \\
\hline seventh decile & 3.86 & 4.06 \\
\hline eighth decile & 4.10 & 3.80 \\
\hline ninth decile & 4.14 & 4.14 \\
\hline tenth decile & 4.48 & 4.23 \\
\hline
\end{tabular}

first decile - the least developed 10 percent of districts; tenth decile - the most developed 10 percent of districts, according to Government Decree

Table 7. The coefficients showing a relationship between the availability of PE facilities in primary schools, as well as the level of development of the district and the average population size of the settlements in the district

(Data source: KIR database of the Educational Authority)

\begin{tabular}{|l|c|c|}
\hline & $\begin{array}{c}\text { Spearmann rank correlation } \\
\text { coefficient }\end{array}$ & $\begin{array}{c}\text { Pearson correlation } \\
\text { coefficient }\end{array}$ \\
\hline $\begin{array}{l}\text { primary schools - the level of } \\
\text { development of the district }\end{array}$ & $0.217^{1}$ & $0.220^{1}$ \\
\hline $\begin{array}{l}\text { primary schools - the average population } \\
\text { size of the settlements in the district }\end{array}$ & $0.352^{1}$ & $0.242^{1}$ \\
\hline
\end{tabular}

1 - significant at 0.01 level, 2 - significant at 0.05 level

In case of secondary schools (table 8 and 9), the availability of PE facilities has a stronger link with the level of developments of the districts. In my opinion, the difference between the two types of institutions can be traced back to the fact that it is particularly true for primary schools that the institutions operating on larger settlements have more students, which - as mentioned before - can provide better conditions. 
Table 8. The availability of PE facilities in secondary schools as a function of the districts' level of development and the average population size of the district's settlements (on the basis of the method presented in Table 2, the average score assigned to the schools in the given decile)

(Data source: KIR database of the Educational Authority, 290/2014. (XI. 26.) on the classification of beneficiary districts, National Territorial Development and Spatial Planning Information System)

\begin{tabular}{|l|c|c|}
\hline & $\begin{array}{c}\text { the level of development of the } \\
\text { district }\end{array}$ & $\begin{array}{c}\text { the average population size of the } \\
\text { settlements in the district }\end{array}$ \\
\hline first decile & 3.14 & 3.39 \\
\hline second decile & 3.14 & 3.72 \\
\hline third decile & 3.09 & 3.25 \\
\hline fourth decile & 3.37 & 2.96 \\
\hline fifth decile & 3.93 & 3.49 \\
\hline sixth decile & 3.35 & 3.51 \\
\hline seventh decile & 3.41 & 3.50 \\
\hline eighth decile & 4.05 & 3.80 \\
\hline ninth decile & 3.83 & 4.11 \\
\hline tenth decile & 4.08 & 3.74 \\
\hline
\end{tabular}

first decile - the least developed 10 percent of districts; tenth decile - the most developed 10 percent of districts, according to Government Decree

Table 9. The coefficients showing a relationship between the availability of PE facilities in secondary schools, as well as the level of development of the district and the average population size of the settlements in the district

(Data source: KIR database of the Educational Authority)

\begin{tabular}{|l|c|c|}
\hline & $\begin{array}{c}\text { Spearmann rank } \\
\text { correlation coefficient }\end{array}$ & $\begin{array}{c}\text { Pearson correlation } \\
\text { coefficient }\end{array}$ \\
\hline $\begin{array}{l}\text { secondary schools - the level of development } \\
\text { of the district }\end{array}$ & $0.375^{1}$ & $0.374^{1}$ \\
\hline $\begin{array}{l}\text { secondary schools - the average population size } \\
\text { of the settlements in the district }\end{array}$ & $0.201^{2}$ & 0.122 \\
\hline
\end{tabular}

1 - significant at 0.01 level, 2 - significant at 0.05 level

Table 10. The proportion of institutions other than general grammar schools in districts at different levels of socio-economic development

(Data source: KIR database of the Educational Authority, 290/2014. (XI. 26.) on the classification of beneficiary districts)

\begin{tabular}{|l|c|}
\hline the level of development of the district & $\begin{array}{c}\text { proportion of institutions other than general } \\
\text { grammar schools }\end{array}$ \\
\hline first decile & 60.9 \\
\hline second decile & 61.6 \\
\hline third decile & 60.3 \\
\hline fourth decile & 62.5 \\
\hline fifth decile & 64.8 \\
\hline sixth decile & 63.8 \\
\hline seventh decile & 65.7 \\
\hline eighth decile & 66.7 \\
\hline ninth decile & 65.9 \\
\hline tenth decile & 69.4 \\
\hline
\end{tabular}

first decile - the least developed 10 percent of districts; tenth decile - the most developed 10 percent of districts, according to Government Decree

By contrast, in case of secondary schools, in more developed districts, there is a higher proportion of institutions (table 10) other than general grammar schools (vocational grammar schools and vocational secondary schools), which are in a better position in terms of the availability of PE facilities than grammar schools (the relevant value is 3.67 in case 
of the former and 3.57 in case of the latter). The proportion of the territorial units concerned within more developed districts can be attributed to the fact that in most cases they include one or two larger settlements which have experienced significant socioeconomic development in the past few decades (including the period before 1990). At the same time, in the framework of the above - in addition to the earlier existing general grammar schools - numerous other new vocational grammar schools and trade schools have been established in the interest of satisfying the needs of the economy and these have been built with suitable sports infrastructure.

An examination of the availability of PE facilities at settlement level reveals the outstanding role played by the size of the settlement both in case of primary and secondary schools (table 11 and 12): with the increase of population size in a settlement, the availability of PE facilities also improves significantly. This situation can be explained by similar factors in case of both institution types: on the one hand, larger settlements are characterized by schools with larger student bodies, which are in a better position in terms of the availability of PE facilities, as shown in Table 5. On the other hand (and partly this is what justifies the previous point), the majority of institutions on larger settlements were built in the past few decades, when bigger attention was already devoted to the construction of schools with suitable sports facilities.

Table 11. The availability of physical education facilities at primary schools as a function of the population size of the settlements

(Data source: KIR database of the Educational Authority, National Territorial Development and Spatial Planning Information System)

\begin{tabular}{|l|c|}
\hline population size of settlements & $\begin{array}{c}\text { score indicating the availability of } \\
\text { facilities }\end{array}$ \\
\hline less than 500 inhabitants & 2.45 \\
\hline $501-1,000$ inhabitants & 3.17 \\
\hline $1,001-1,500$ inhabitants & 3.47 \\
\hline $1,501-2,000$ inhabitants & 3.81 \\
\hline $2,001-3,000$ inhabitants & 3.96 \\
\hline $3,001-5,000$ inhabitants & 4.33 \\
\hline $5,001-10,000$ inhabitants & 4.17 \\
\hline $10,001-25,000$ inhabitants & 4.26 \\
\hline $25,001-50,000$ inhabitants & 4.62 \\
\hline $50,001-100,000$ inhabitants & 4.71 \\
\hline more than 100,000 inhabitants & 4.63 \\
\hline Budapest & 4.66 \\
\hline
\end{tabular}

Table 12. The availability of physical education facilities at secondary schools schools as a function of the population size of the settlements

(Data source: KIR database of the Educational Authority, National Territorial Development and Spatial Planning Information System)

\begin{tabular}{|l|c|}
\hline population size of settlements & score indicating the availability of facilities \\
\hline less than 3,000 inhabitants & 2.41 \\
\hline $3,000-5,000$ inhabitants & 2.60 \\
\hline $5,000-7,500$ inhabitants & 3.30 \\
\hline $7,500-10,000$ inhabitants & 3.24 \\
\hline $10,000-25,000$ inhabitants & 3.65 \\
\hline $25,000-50,000$ inhabitants & 4.02 \\
\hline $50,000-100,000$ inhabitants & 3.99 \\
\hline 100,000 fö felett & 3.97 \\
\hline Budapest & 3.99 \\
\hline
\end{tabular}




\section{CONCLUSIONS}

The most important findings of the study could be summarised as follows. The availability of physical education facilities at Hungarian educational institutions is fundamentally favourable: a significant proportion of the students attend schools that have both indoor and outdoor facilities. With the increase in the number of students enrolled in the schools, the capabilities of schools providing for the needs of physical education classes at a proper level significantly improve. Examining the territorial conditions on the district level, in case of primary schools, it is the average population size, while in case secondary schools, it is the level of development of the districts that are the most important factors. The analysis of the data at settlement level revealed that institutions operating on settlements with a larger population can generally offer better conditions for physical education.

\section{Acknowledgements}

This study was supported by the EFOP-3.6.2-16-2017-00003 project which is financed by the European Union and the European Social Fund.

\section{REFERENCES}

Ardoy, D. N., Fernández-Rodríguez, J. M., Jiménez-Pavón, D., Castillo, R., Ruiz, J. R., \& Ortega, F. B. (2014). A physical education trial improves adolescents' cognitive performance and academic achievement: the EDUFIT study. Scandinavian journal of medicine \& science in sports, 24(1), 52-61.

Baidog, A., \& Herman, G.V. (2018). The Influence of Sports and Physical Activity on the Metabolic Syndrome: A Systematic Review. Analele Universităţii din Oradea. Fascicula Educaţie Fizică şi Sport, 28(1), 39-45.

Bánhidi, M. (2011). Sportföldrajz [Sport geography], Dialóg Campus Kiadó, Budapest - Pécs (in Hungarian).

Dobi, B., \& Bácsné Bába, É. (2018). A mindennapos testnevelés megítélése általános iskolások, szüleik és tanáraik szerint egy iskolai vizsgálatra alapozva [Judging everyday physical education according to primary school pupils, their parents and teachers based on investigation of a primary school]. In. (ed. by Balogh, L.) Válogatott tanulmnyok a sporttudományok köréböl [Studies on sports sciences], University of Debrecen, Institute of Sports Sciences, Debrecen, 73-84.

Dubbert, P. M. (2002). Physical activity and exercise: Recent advances and current challenges. Journal of consulting and clinical psychology,70(3), 526-536.

Erdely, Ș., Caciora, T., Șerbescu, C., Papp, B.M., Tamas, F.A., Bujorean, E., Baidog, A., Furdui, S., Ile, M., \&Herman, G.V. (2020). Trends in the lifestyle of students. Case study of a high school in Oradea, Romania. Geosport for Society, 12(1), 1-12.

Gordon-Larsen, P., McMurray, R. G., \& Popkin, B. M. (2000). Determinants of adolescent physical activity and inactivity patterns. Pediatrics, 105(6), e83-e83.

Hagger, M. S., Chatzisarantis, N. L., Culverhouse, T., \& Biddle, S. J. (2003). The processes by which perceived autonomy support in physical education promotes leisure-time physical activity intentions and behavior: a trans-contextual model. Journal of educational psychology, 95(4), 784-795.

Hoekman, R., Breedveld, K., \& Kraaykamp, G. (2016). A landscape of sport facilities in the Netherlands. International Journal of Sport Policy and Politics, 8(2), 305-320.

Ilies, A., Dehoorne, O., Wendt, J., \& Kozma, G. (2014). For Geography and Sport, Sport Geography or Geography of Sport. Geosport for Society, 1(1-2), 5-12.

Kozma, G. (2014). The spatial development of sports facilities within the cities: a Central European case study. Geosport for Society, 1(1-2), 13-20.

Kozma, G. (2020). The spatial characteritics of the infrastructural background of physical education (PE) classes in Hungarian kindergartens. GeoSport for Society, 12(1), 13-23.

Marques, A., Corrales, F. R. G., Martins, J., Catunda, R., \& Sarmento, H. (2017). Association between physical education, school-based physical activity, and academic performance: a systematic review. Retos: nuevas tendencias en educación física, deporte y recreación, 31, 316-320.

Mikulán, R. (2013). Az iskolai testnevelés szerepe és jelentősége az egészségfejlesztésben [The role and importance of physical education in health promotion]. Új pedagógiai szemle 63(7-8), 48-69.

Papp, B.M., Șerbescu, C., Caciora, T., Baidog, A., Varodi, M.O. (2019). The Effects of a Physical Activity Program on Body Composition and Physical Condition in the Overweight Adult. Analele Universităţii din Oradea. Fascicula Educaţie Fizică şi Sport, 29(1), 1-9.

Polet, J., Hassandra, M., Lintunen, T., Laukkanen, A., Hankonen, N., Hirvensalo, M., Tammelin, T., \& Hagger, M. S. (2019). Using physical education to promote out-of school physical activity in lower secondary school studentsa randomized controlled trial protocol. BMC public health, 19(1), 157. 
Strong, W. B., Malina, R. M., Blimkie, C. J. R., Daniesl, S. R., Dishman, R. K., Gutin, B., Hergenroeder, A. C., Must, A., Nixon, P. A., Pivarnik, J. M., Rowland, T., Trost, S., \& Trudeau, F. (2005). Evidence based physical activity for school-age youth. The Journal of Pediatrics, 146(6), 732-737.

Tassitano, R. M., Barros, M. V., Tenório, M. C., Bezerra, J., Florindo, A. A., \& Reis, R. S. (2010). Enrollment in physical education is associated with health-related behavior among high school students. Journal of School Health, 80(3), 126-133.

Tătar, C.F., Herman, G. V., \& Pețan, P. (2018). Sport and physical activity engagement in Romania. Geosport for Society, $8(1), 40-50$.

Tsang, E. C. (2011). A Comparison on the Effect of Doing Exercise, Listening to Music and Taking Quiet Rest on Mood Changes. Asian Journal of Physical Education \& Recreation, 17(1), 37-44.

Van Dusen, D. P., Kelder, S. H., Kohl, H. W., Ranjit, N., \& Perry, C. L. (2011). Associations of physical fitness and academic performance among schoolchildren. Journal of School Health, 81(12), 733-740.

Wise, N., \& Kohe, G. Z. (2020). Sports geography: new approaches, perspectives and directions, Sport in Society, 23(1), 1-10.

Submitted:

March 25, 2020
Revised:

April 27, 2020
Accepted and published online

May 08, 2020 